\title{
Hubungan antara Frekuensi Penggunaan Media Pendidikan dengan Motivasi Belajar Mahasiswa
}

\author{
Ismail ${ }^{1}$, Isna Farahsanti ${ }^{2}$ \\ 1,2Universitas Veteran Bangun Nusantara \\ E-mail : ismail.univetbantara@gmail.com
}

\begin{abstract}
Abstrak
Tujuan penelitian ini adalah untuk mengetahui adakah hubungan yang signifikan antara penggunaan media pendidikan dengan motivasi belajar mahasiswa FKIP Univet Bantara Sukoharjo. Populasi dalam penelitian ini adalah seluruh mahasiswa FKIP Univet Bantara Sukoharjo yang berjumlah 1130, sedangkan sampelnya adalah sebagian dari populasi yang berjumlah 113 mahasiswa dengan cara pengambilan sampelnya adalah proporsional random sampling, cara pengambilan data dengan metode angket yang digunakan untuk mengungkap data tentang frekuensi penggunaan media dan motivasi belajar mahasiswa sedangkan analisis data dengan menggunakan teknik korelasi serial. Hasil penelitian ini menunjukkan bahwa ada korelasi positif signifikan antara frekuensi penggunaan media pendidikan dengan motivasi belajar mahasiswa FKIP Univet Bantara Sukoharjo, dengan demikian semakin tinggi frekeunsi penggunaan media pendidikan maka semakin tinggi motivasi belajar mahasiswa sebaliknya semakin rendah frekuensi penggunaan media pendidikan maka semakin rendah pula motivasi belajar mahasiswa
\end{abstract}

Kata Kunci: Frekuensi penggunaan media, motivasi belajar

\section{The Relation Between The Frequency of Use An Educational Media with Student Learning Motivation}

\author{
Ismail', Isna Farahsanti ${ }^{2}$ \\ ${ }^{1,2}$ Universitas Veteran Bangun Nusantara \\ E-mail : ismail.univetbantara@gmail.com
}

\begin{abstract}
The purpose of this study was to determine whether there is a significant relationship between the use of educational media and the learning motivation of FKIP students at Bantara Sukoharjo University. The population in this study were all 1130 students of FKIP Univet Bantara Sukoharjo, while the sample was part of the population of 113 students by means of proportional random sampling, the method of collecting data was the questionnaire method used to reveal data about the frequency of media use and student learning motivation while data analysis using serial correlation technique. The results of this study indicate that there is a significant positive correlation between the frequency of using educational media and the learning motivation of FKIP Bantara Sukoharjo University students, thus the higher the frequency of using educational media, the higher the student's learning motivation. college student
\end{abstract}

Keywords: Frequency of media use, learning motivation. 


\section{PENDAHULUAN}

Media merupakan suatu bagian yang integral dari proses pendidikan di suatu lembaga pendidikan. Media merupakan alat yang disalurkan untuk mengungkapkan suatu ide, gagasan atau pendapat sehingga dapat dikemukakan kepada penerima (Pradilasari et al., 2019). Media pendidikan ini dapat membantu tercapainya proses belajar mengajar yang dapat mendorong siswa untuk belajar lebih aktif lagi dalam mencapai tujuan yang diharapkan. Dengan media pendidikan, hal - hal yang abstrak bisa menjadi konkrit, sehingga diharapkan proses pembelajaran dapat berjalan secara efektif dan efisien. Dengan kata lain, pengalaman yang diperoleh tidak verbalisme, dengan demikian mahasiswa akan memperoleh pengalaman yang lebih luas lagi.

Motivasi merupakan faktor yang sangat penting di dalam belajar. Karena motivasi merupakan suatu pendorong bagi mahasiswa untuk belajar. Dengan kata lain motivasi belajar mahasiswa dapat ditimbulkan oleh tenaga pengajar/dosen dalam proses belajar. Dipilihlah mahasiswa Fakultas Keguruan dan IImu Pendidikan karena mahasiswa tersebut merupakan calon guru dimana dia harus mempunyai pengalaman yang cukup di bidang keguruan khususnya tentang media pendidikan yang diterapkan oleh dosen dalam proses belajar mengajar sehingga mahasiswa dapat menerapkan ketika menjadi pengajar.

Penggunaan media pendidikan dalam proses pembelajaran akan sangat membantu memberikan pengalaman yang mendekati konkrit kepada mahasiswa, hal ini akan lebih mendorong mahasiswa untuk lebih jauh lagi karena dengan digunakan media pendidikan pelajaran tidak membosankan dan lebih menarik. Media pembelajaran adalah alat bantu dalam proses belajar mengajar untuk merangsang pikiran, perhatian dan kemampuan atau keterampilan pembelajar sehingga dapat mendorong terjadinya proses belajar (Tafonao, 2018).

Media pendidikan merupakan sarana pendidikan sebagai perantara dalam proses pembelajaran yang dapat menyalurkan materi pembelajaran, yang dapat merangsang pikiran, perasaan dan kemauan siswa sehingga dapat mendorong terciptanya proses belajar pada dirinya untuk lebih mempertinggi efektivitas dan efisiensi dalam mencapai tujuan pendidikan sehingga proses pembelajaran lebih berkualitas. Media pendidikan merupakan alat bantu yang terjadi dalam proses pembelajaran, dengan adanya media pendidikan membantu proses penyampaian pesan - pesan dari bahan 
pelajaran yang disampaikan guru kepada peserta didik (Abdullah, 2016).

Media pembelajaran merupakan alat yang dapat membantu guru dalam proses belajar mengajar dan berfungsi untuk membantu dalam menyampaikan pesan kepada siswa sehingga dapat mencapai tujuan pendidikan dan hasil belajar siswa menjadi lebih baik. Dengan media pembelajaran maka kualitas belajar menjadi meningkat (Nurrita, 2018). Sehingga media sangat dibutuhkan dalam pembelajaran agar pembelajaran dapat berjalan secara optimal.

Menurut (Sanjaya, 2014), fungsi dari penggunaan media pembelajaran yaitu: Fungsi motivasi, bahwa media pembelajaran dapat memotivasi siswa dalam belajar. Dengan pengembangan media pembelajaran tidak hanya mengandung unsur artistik saja akan tetapi memudahkan siswa mempelajari materi pelajaran sehingga dapat meningkatkan gairah siswa untuk belajar. Dengan diketahui fungsi media pendidikan maka jelaslah bahwa media pendidikan sangat penting dalam proses pembelajaran dan dapat memberikan motivasi belajar siswa/mahasiswa.
Media pembelajaran berperan penting dalam pembelajaran guna membantu menyampaikan informasi atau materi yang akan disampaikan seorang guru ke peserta didik. Seiring perkembangan jaman media pembelajaran berkembang secara cepat sesuai dengan pembelajaran inovatif abad 21 yang berbasis ICT (Information Communication and Tecnology) (Novitasari et al., 2019). Selanjutnya menurut (Setiawan, 2019) Penggunaan media pembelajaran sangat dibutuhkan dalam proses pembelajaran, agar materi pelajaran dapat tersampaikan dengan baik, maka diperlukan adanya media pembelajaran yang menunjang tercapainya tujuan pembelajaran, sehingga tujuan pembelajaran dapat tercapai sesuai yang diharapkan.

Proses pembelajaran pada dasarnya tediri dari dua kegiatan, yaitu Dosen yang mengajar dan mahasiswa yang belajar. Sebagai seorang dosen, ia harus dapat menciptakan lingkungan/kondisi belajar yang baik agar mahasiswa dapat belajar dengan baik pula. Menciptakan lingkungan yang baik dalam proses belajar dapat dimulai, dengan adanya suatu tujuan yang jelas. Untuk mencapai tujuan pendidikan itu diperlukan suatu bekal yang cukup berupa isi pelajaran yang menuntut aktivitas belajar dari mahasiswa dalam 
setiap proses belajar mengajar berlangsung.

Untuk membantu pencapaian tujuan yang telah ditetapkan, diperlukaan suatu sarana yang merangsang aktivitas mahasiswa. Dalam proses pembelajaran akan terjadi bila adanya aktivitas mahasiswa dan dosen yang dapat menciptakan lingkungan belajar yang baik. Untuk itu diperlukan tersedianya sarana pendidikan yang berupa media pendidikan sehingga dapat memperlancar proses pembelajaran.

Media pendidikan sebagai sarana untuk memperlancar proses pembelajaran memang tidak dapat ditinggalkan begitu saja. Peranannya sangat besar dalam proses pembelajaran. tetapi bukan berarti suatu media selalu tepat dengan semua materi yang akan diajarkan kepada mahasiswa. Hal ini perlu adanya pemilihan tentang media pendidikan sebelum suatu media dipergunakan dalam proses pembelajaran. Dengan demikian hal - hal yang perlu diperhatikan dalam pemilihan media pendidikan berarti dapat membantu memperlancar proses pembelajaran.

Menurut (Umar, 2014) Kriteria yang paling utama dalam pemilihan media bahwa media harus disesuaikan dengan tujuan pembelajaran atau kompetensi yang ingin dicapai. Contoh: bila tujuan atau kompetensi peserta didik bersifat menghafalkan kata-kata tentunya media audio yang tepat untuk digunakan. Jika tujuan atau kompetensi yang dicapai bersifat memahami isi bacaan maka media cetak yang lebih tepat digunakan. Kalau tujuan pembelajaran bersifat motorik (gerak dan aktivitas), maka media film dan video bisa digunakan. Adanya kemajuan TIK dan multimedia saat ini membantu dalam pembelajaran secara linguistik yang dirancang ke dalam bentuk konten yang direkam kemuadian di salurkan kepada peserta didik untuk menggantikan guru (Muslem \& Abbas, 2017). Di samping itu, terdapat kriteria lainnya yang bersifat melengkapi (komplemen), seperti: biaya, ketepatgunaan; keadaan peserta didik; ketersediaan; dan mutu teknis. Peranan media pendidikan dalam proses pembelajaran tidak terlepas dari fungsi media itu sendiri dalam proses pembelajaran. Pada dasarnya fungsi media pendidikan dalam proses belajar mengajar yaitu memperlancar proses pembelajaran itu sendiri, yaitu untuk mencapai tujuan pendidikan yang telah ditetapkan sebelumnya. Kegiatan pembelajaran memiliki tujuan yaitu perubahan tingkah laku mahasiswa, oleh karena itu media pendidikan yang digunakan oleh dosen hendaknya memudahkan mahasiswa untuk memahami masalah-masalah yang dihadapi dalam belajar. 
Menurut (Nurrita, 2018) bahwa manfaat media pembelajaran bagi siswa/mahasiswa, yaitu: dapat meningkatkan motivasi dan minat belajar siswa/mahasiswa sehingga dapat berpikir dan menganalisis materi pelajaran yang diberikan oleh guru/dosen dengan baik dengan situasi belajar yang menyenangkan dan siswa dapat memahami materi pelajaran dengan mudah. Manfaat penggunaan media pembelajaran diantaranya: membangkitkan motivasi, sehingga dapat memperbesar perhatian peserta didik, pembelajaran tidak membosankan dan tidak monoton, memfungsikan seluruh indera siswa/ mahasiswa (Muhson, 2010).

Motivasi belajar mahasiswa merupakan dorongan baik dari dalam maupun dari luar untuk mencapai tujuan yang diinginkan. Dalam kegiatan belajar, motivasi mempunyai peranan yang sangat penting, motivasi dalam belajar merupakan pendorong seseorang untuk belajar. Motivasi yang dapat mendorong seseorang belajar disebut motivasi belajar.

Menurut (Masni, 2017), motivasi itu merupakan dorongan dasar yang menggerakkan seseorang dalam bertingkah laku dalam mencapai suatu tujuan. Dengan demikian dapat dikatakan bahwa motivasi belajar mahasiswa adalah keseluruhan daya penggerak di dalam diri mahasiswa yang menimbulkan kegiatan belajar/proses perkuliahan yang menjamin kelangsungan dan yang memberikan arah pada kegiatan belajar, sehingga tujuan yang dikehendaki oleh subjek belajar itu dapat tercapai (Sugiyono, 2015). Selanjutnya Sugiyono mengatakan bahwa Motivasi memegang peranan yang sangat penting dalam kegiatan belajar di perguruan tinggi, dan motivasi dipengaruhi oleh tujuan yang akan dicapai dengan belajar, semakin tinggi tujuan belajar maka akan semakin tinggi motivasinya, dan semakin tinggi motivasi belajarnya akan semakin kuat pula kegiatan belajarnya. Perilaku belajar berkaitan erat dalam membentuk suatu kesatuan yang disebut sebagai proses motivasi belajar (Sugiyono, 2015).

Berdasar paparan di atas dapat dikatakan bahwa motivasi itu merupakan dorongan dasar yang menggerakkan seseorang dalam bertingkah laku dalam mencapai suatu tujuan. Dengan demikian yang dimaksud dengan motivasi belajar mahasiswa adalah keseluruhan daya penggerak di dalam diri mahasiswa yang menimbulkan kegiatan belajar/proses perkuliahan yang menjamin kelangsungan dan yang memberikan arah pada kegiatan belajar, sehingga tujuan yang dikehendaki oleh mahasiswa itu dapat tercapai secara optimal. 
Motivasi dalam belajar merupakan seluruh dorongan baik secara instrinsik maupun ekstrinsik yang menimbulkan aktivitas belajar, yang menjamin pelaksanaan kegiatan belajar dan yang menuntun aktivitas belajar sehingga tujuan yang inginkan dapat tercapai secara optimal. Hal ini selaras dengan motivasi belajar merupakan pendorong untuk individu melakukan aktivitas belajar tertentu yang diperoleh dari diri sendiri maupun dari luar individu sehingga mampu menumbuhkan semangat belajar (Andriani \& Rasto, 2019; Emda, 2017). Menurut (Mediawati, 2010) Adanya motivasi yang baik dalam belajar akan menunjukan hasil yang baik. Dengan kata lain, dengan adanya usaha yang tekun dan terutama disadari adanya motivasi, maka seseorang yang belajar itu akan dapat melahirkan prestasi yang baik". Tingkat keberhasilan suatu pembelajaran ditentukan melalui tingkat motivasi siswa (Machfudi, 2016). Di dalam kegiatan belajar, motivasi perlu ditumbuhkan, tanpa memilki motivasi belajar, maka sulitlah bagi mahasiswa untuk melaksanakann kegiatan belajar. Dalam pelaksanaan pembelajaran di Perguruan Tinggi agar diperoleh hasil belajar yang optimal, maka mahasiswa perlu memiliki motivasi belajar yang tinggi. Dengan adanya motivasi belajar yang tinggi diharapkan dapat membantu pencapaian tujuan belajar bagi mahasiswa. Mahasiswa membutuhkan dorongan atau penggerak untuk melaksana kan kegiatan belajar di perguruan tinggi sehingga dapat memperoleh tujuan belajar yang diinginkan. Dorongan atau penggerak inilah yang sering disebut motivasi.

Proses Pembelajaran di Perguruan tinggi pada hakekatnya adalah interaksi antara dosen dan mahasiswa, interaksi ini dilakukan dengan sengaja agar dapat menghasilkan perubahan tingkah laku pada diri mahasiswa yang belajar. perubahan tingkah laku yang dimaksud menyangkut aspek kognitif afektif dan psikomotorik, perubahan tingkah laku ini sangat diharapkan dalam proses pembelajaran sehingga dapat mencapai tujuan pendidikan yang telah ditetapkan sebelumnya. Dengan demikian mahasiswa terarah dalam belajar yaitu kepada tercapainya suatu tujuan. Bagi seorang dosen, maka perlu memiliki kreativitas dan inovasi yang tinggi untuk menciptakan daya tarik yang dapat memberi motivasi mahasiswa, untuk mencapai tujuan yang diinginkan. sebab motivasi merupakan dorongan baik dari dalam maupun dari luar yang dapat mempengaruhi tingkah laku untuk melakukan sesuatu kegiatan, maka mahasiswa yang memiliki motivasi belajar secara otomatis memiliki gairah untuk belajar. Membangkitkan motivasi belajar 
mahasiswa memerlukan upaya yang harus dilakukan. Salah satu upaya untuk membangkitkan motivasi belajar mahasiswa perlu menggunakan media pendidikan yang menarik. sehingga dapat membangkitkan gairah belajar mahasiswa yang diharapkan proses pembelajaran lebih berkualitas yang pada gilirannya prestasi belajar mahasiswa lebih mengingkat.

Senada dengan hasil penelitian (Ali \& Zaini, 2020) menyatakan bahwa pemanfataan program google classroom perkuliahan dasar-dasar kependidikan dapat meningkatkan motivasi belajar mahasiswa. Dengan demikian upaya untuk menarik perhatian dan meningkatkan motivasi belajar mahasiswa, dosen hendaknya memilih metode yang tepat atau cara yang relevan dengan isi dan tujuan pembelajaran yang akan disampaikan. Oleh karena itu media pendidikan yang digunakan dosen hendaknya memberi kemudahan mahasiswa dalam memahami masalah - masalah belajar yang dihadapinya. Secara teoritis penggunaan media pendidikan dapat sebagai perangsang timbulnya motivasi belajar mahasiswa. Oleh karena itu dalam penggunaan media pendidikan oleh dosen setiap proses pembelajaran akan sangat membantu mahasiswa siswa dalam menerima pelajaran. Semakin dosen sering menggunakan media pendidikan maka motivasi mahasiswa akan meningkat. Dengan kata lain semakin frekuensi penggunaan media tinggi maka motivasi belajar juga sangat tinggi.

Tujuan penelitian ini adalah untuk mengetahui adakah hubungan yang postif signifikan antara frekuensi penggunaan media pendidikan dengan motivasi belajar mahasiswa fakultas keguruan dan ilmu pendidikan Universitas Veteran Bangun Nusantara Sukoharjo, dengan mengajukan hipotesis: Bahwa ada hubungan yang positif signifikan antara frekuensi penggunaan media pendidikan dengan motivasi belajar mahasiswa FKIP Universitas Veteran Bangun Nusantara Sukoharjo.

Diharapkan hasil penelitian ini dapat memberi kontribusi terhadap lembaga pendidikan dalam kaitannya membuat kebijakan tentang sarana dan prasarana pendidikan serta pengguaan media pendidikan dalam pembelajaran bagi dosen. 


\section{METODE}

Peneliti menggunakan pendekatan kuantitatif karena penelitian ini dilakukan untuk mengetahui hubungan antara frekuensi penggunaan media dengan motivasi belajar mahasiswa FKIP Universitas Veteran Bangun Nusantara Sukoharjo. Menurut (Sugiyono, 2013) metode kuantitatif dapat diartikan sebagai metode penelitian yang berlandaskan pada filsafat positivisme, digunakan untuk meneliti pada populasi atau sampel tertentu, pengumpulan data menggunakan instrumen penelitian analisis data bersifat kuantitatif/ statistik, dengan tujuan untuk menguji hipotesis yang telah ditetapkan.

Penelitian yang digunakan adalah penelitian kuantitatif yang mengungkap kebenaran bentuk hubungan antar variabel atau fenomena. Ciri dalam penelitian kuantitatif yaitu teknik analisis datanya menggunakan teknik kuantitatif (statistika) secara objektif (Creswell, 2013). Populasi adalah keseluruhan subyek penelitian yang dijadikan subyek penelitian.

Menurut (Sugiyono, 2015) menyatakan populasi adalah wilayah generalisasi yang terdiri atas obyek/subyek yang mempunyai kualitas dan karekteristik tertentu yang ditetapkan oleh peneliti untuk dipelajari dan kemudian ditarik kesimpulannya. Penelitian ini populasinya adalah seluruh mahasiswa FKIP Universitas Veteran Bangun Nusantara Sukoharjo yang berjumlah 1130 mahasiswa, sedangkan sampel adalah sebagian atau wakil dari populasi yang dijadikan subyek penelitian dan diharapkan hasil yang diperoleh dapat memberi gambaran yang representatif bagi populasi, sampel penelitian ini berjumlah 113 mahasiswa dengan menggunakan proporsional random sampling, teknik pengumpulan data dengan angket sedangkan analisis data dengan korelasi serial

\section{HASIL DAN PEMBAHASAN}

\section{Uji Validitas Dan Uji Reliabilitas}

Untuk mengetahui validitas (ketepatan/kesahihan) dan reliabilitas (ketetapan/keajegan) angket penelitian, maka sebelum angket dikenakan beberapa subjek penelitian yang sesungguhnya, peneliti terlebih dahulu mengadakan uji coba.

Uji Validitas

Untuk mengetahui validitas (ketepatan/kesahihan) alat ukur, penelitian menggunakan logical validity. Sebab dalam penyusunan angket bertitik tolak dari kerangka teoritik dengan memperhatikan 
hubungan yang logis antara alat ukur dengan teori dan definisi tentang frekuensi penggunaan media pendidikan dan juga memperhatikan hubungan yang logis antara alat ukur dengan teori dan definisi tentang motivasi belajar. Dengan demikian item - item dalam angket secara logis teoritis dinyatakan valid. Dengan demikian alat ukur ini (angket) dapat digunakan untuk penelitian

\section{Uji Reliabilitas}

Untuk menguji reliabilitas (ketetapan/keajegan) dalam penelitian ini dengan menggunakan teknik belah dua dengan rumus product moment. Untuk menguji reliabilitas angket yang mengungkapkan tentang frekuensi penggunaan media pendidikan dari hasil perhitungan yang peneliti laksanakan

Adalah $r=0,79$, nilai pada tabel 0,361 untuk taraf signifikasi 5\%. Dengan demikian berarti untuk uji coba sejumlah 30 subjek antara item gasal dan genap adalah signifikan.

Untuk mengetahui uji reliabilitas angket yang mengungkapkan tentang motivasi belajar, dari hasil perhitungan dapat diperoleh nilai korelasi 0,798 , nilai $r$ pada tabel 0,361 untuk taraf signifikan 5\% dan 0,453 untuk taraf signifikan $1 \%$. Dengan demikian antara item gasal dan genap adalah signifikan. Ini berarti angket tersebut dapat digunakan pelaksanaan penelitian.

\section{Tahap analisis data}

Dalam tahap analisis data ini, mengolah data yang sudah terkumpul dengan memberi skor terhadap tiap - tiap item dari angket menjumlahkan skor item dari setiap subjek penelitian kemudian menghitung atau menganalisis hasil dari skor yang diperoleh. Karena dalam menganalisis data ini dengan menggunakan teknik analisis statistik maka hipotesis alternatif harus dinihilkan terlebih dahulu, sehingga HO berbunyi Tidak ada hubungan antara frekuensi penggunaan media pendidikan dengan motivasi belajar mahasiswa FKIP Universitas Bangun Nusantara Sukoharjo, sedangkan teknik analisisnya dengan menggunakan teknik analisis korelasi serial, dengan rumus sebagai berikut :

$$
r \text { ser }=\frac{\sum\left\{\left(0_{\mathrm{t}}-0_{\mathrm{m}}\right)(\mathrm{M})\right\}}{\mathrm{SD} \text { tot } \Sigma\left[\frac{\left(0_{\mathrm{r}}-0_{\mathrm{t}}\right)^{2}}{\mathrm{P}}\right]}
$$

\section{Keterangan}

R ser = Korelasi serial

(Or-0t) $(\mathrm{M})=$ Ordinat rendah dikurangi ordinat tinggi dikali Mean

$$
\begin{array}{ll}
\mathrm{SD} \text { tot } & =\text { Standart deviasi total } \\
\mathrm{P} & =\text { Proporsi individu dalam }
\end{array}
$$

kelompok 
$(\mathrm{Or}-\mathrm{ot})^{2}$

$\mathrm{p} \quad=$ Ordinat rendah dikurangi ordinat tinggi dikuadratkan, dibagi proporsi individu dalam kelompok

Setelah nilai $\mathrm{t}$ ditemukan, langkah selanjutnya adalah mengkonsultasikan nilai $\mathrm{t}$ yang diperoleh, dengan nilai $\mathrm{t}$ dalam tabel. Menurut harga kritik t, emperis yang diperoleh sebesar 3,37 itu signifikan pada interval kepercayaan 95\% sebesar 2,00, maupun pada interval kepercayaan 99\% sebesar 2,266. Dengan demikian hipotesis nihil yang berbunyi: Tidak ada hubungan antara frekuensi penggunaan media pendidikan dengan motivasi belajar ditolak Itu berarti hipotesis alternatif yang berbunyi Ada hubungan antara frekuensi penggunaan media pendidikan dengan motivasi belajar diterima

\section{SIMPULAN DAN SARAN}

Berdasarkan analisis data yang diperoleh, maka dapat diambil kesimpulan Ada hubungan yang positif dan signifikan antara frekuensi penggunaan media pendidikan dengan motivasi belajar mahasiswa Ini berarti bahwa semakin tinggi frekuensi penggunaan media pendidikan oleh dosen dalam proses pembelajaran maka tinggi pula motivasi belajar mahasiswa, dan sebaliknya semakin rendah frekuensi penggunaan media pendidikan maka semakin rendah motivasi belajar mahasiswa.

Rekomendasi pertama kepada dosen hendaknya lebih meningkatkan frekuensi penggunaan media pendidikan dalam proses pembelajaran dan diharapkan media yang digunakan bervariasi agar tidak membosankan. Kedua kepada mahasiswa agar motivasi belajarnya meningkat sebaiknya dalam belajar menggunakan media pendidikan yang dapat memudahkan dalam menangkap pelajaran. Ketiga kepada lembaga Pendidikan (FKIP Univet Bantara Sukoharjo) hendaknya menambah sarana dan prasarana pendidikan terutama media pendidikan yang inovatif agar motivasi belajar mahasiswa meningkat.

\section{DAFTAR REFERENSI}

Abdullah, R. (2016). Pembelajaran Dalam Perspektif Kreativitas Guru Dalam Pemanfaatan Media Pembelajaran. Lantanida Journal, 4(1). https://doi.org/10.22373/lj.v4i1.1866

Ali, U., \& Zaini, M. (2020). Pemanfaatan Program Aplikasi Google Classroom sebagai upaya meningkatkan motivasi dan prestasi belajar mahasiswa pada perkuliahan dasar - dasar kependidikan. Jurnal Jurusan Tadris IPS, 11(1), 27-34.

Andriani, R., \& Rasto, R. (2019). Motivasi belajar sebagai determinan hasil belajar siswa. Jurnal Pendidikan Manajemen Perkantoran, 4(1), 80-96. https://doi.org/10.17509/jpm.v4i1.14958

Creswell, J. (2013). Qualitative, Quantitative, and Mixed Methods Approaches.

Emda, A. (2017). Kedudukan Motivasi Belajar Siswa Dalam Pembelajaran. Lantanida Journal, 5(2), 93-196. 
https://doi.org/10.22373/lj.v5i2.2838

Machfudi, M. I. (2016). Issues and Challenges in Maintaining Motivation To Learn English in Rural Madrasah Context. IJET (Indonesian Journal of English Teaching), 5(2), 173-183. https://doi.org/10.15642/ijet2.2016.5.2.1 73-183

Masni, H. (2017). Strategi Meningkatkan Motivasi Belajar Mahasiswa. Jurnal Ilmiah Dikdaya, 5(1), 34-35.

Mediawati, E. (2010). Pengaruh motivasi Belajar Mahasiswa dan Kompetensi Dosen terhadap Prestasi Belajar. Jurnal Pendidikan Ekonomi Dinamika, 5(2), 134136.

Muhson, A. (2010). Pengembangan Media Pembelajaran Berbasis Teknologi Informasi. Jurnal Pendidikan Akuntasi InDONESIA, 8(2).

Muslem, A., \& Abbas, M. (2017). The Effectiveness of Immersive Multimedia Learning with Peer Support on English Speaking and Reading Aloud. Studies in English Language and Education, 10(1), 203-218.

https://doi.org/10.24815/siele.v2i2.2694

Novitasari, D., Ratnawuri, T., \& Pritandhari, M. (2019). Pengembangan Media Pembelajaran Electonic Book (E-Book) berbasis Edmodo kelas $X$ SMK Kartikatama Metro. Jurnal Program Studi Pendidikan Ekonomi, 7(2), 107-115.

Nurrita, T. (2018a). Pengembangan Media Pembelajaran untuk Meningkatkan Hasil Belajar Siswa. Jurnal MISYKAT: IImu Ilmu Al-Qur'an, Hadist, Syari'ah, 3(1).

Nurrita, T. (2018b). PENGEMBANGAN MEDIA PEMBELAJARAN UNTUK MENINGKATKAN HASIL BELAJAR SISWA. Misykat, 03(1), 171-187. https://doi.org/10.1088/17426596/1321/2/022099

Pradilasari, L., Gani, A., \& Khaldun, I. (2019). Pengembangan Media Pembelajaran Berbasis Audio Visual pada Materi Koloid Untuk Meningkatkan Motivasi dan Hasil Belajar Siswa SMA. Jurnal Pendidikan Sains Indonesia, 7(1), 9-15. https://doi.org/10.24815/jpsi.v7i1.13293

Sanjaya, W. (2014). Media Komunikasi Pembelajaran. Kencana Prenada Media Group.

Setiawan, A. (2019). Merancang Media Pembelajaran PAI di Sekolah (Analisis
Implementasi Pembelajaran Berbasis PAI ). Jurnal IImiah Keagamaan, Pendidikan Dan Kemasyarakatan, 10(2).

Sugiyono. (2013). Metode Kuantitatif, Kualitatif, dan R\&D. CV Alfabeta.

Sugiyono. (2015). Metode Penelitian Pendidikan (Pendekatan, Kuantitatif, Kualitatif, dan $R \& D)$. CV Alfabeta.

Tafonao, T. (2018). Peranan Media Pembelajaran dalam Meningkatkan Minat Belajat. Jurnal Komunikasi Pendidikan, 2(2).

Umar. (2014). Media Pendidikan: Peran dan Fungsinya dalam Pembelajaran. Jurnal Tarbiyah, 11(1), 131-144. 